\title{
Community-Based Learning in Vocational Education and Training: Making Schools Closer to The Real World
}

\author{
Waras Kamdi \\ Mechanical Engineering Education, Faculty of Engineering, State University of Malang, \\ East Java, INDONESIA \\ waraskamdi@gmail.com; waras.ft@um.ac.id.
}

\begin{abstract}
It has long been casually observed that more and more students complain about irrelevance of their learning: what is learned in school is no longer related to the needs and challenges in real life. There is no relationship between what is learned in classrooms and what happens outside the classrooms. In the classroom they feel to be treated as a child. Not only that, they are shackled and deprived of meaningful activities related to adult life. In fact, many students see no relationship between their performance in college and employment opportunities after graduation. Conversely, even there are a lot of class activities in college that have no effects on their success in getting a job after graduation. Instead, private trainings which have no relation with higher education activities determine their success in the lives of adults. The question learners often raise: "why should I learn this" actually reflects an awareness of the needs of meaningful learning that is learning that has to do with the real world needs. In short, naturally students are looking for and want to find a real relationship between what is learned at school with the need to enter the real world or everyday life in the community. Community-Based Learning is a potential learning model for vocational training and education that enables schools and the real world become closer.
\end{abstract}

Index Terms-community-based learning, real world, vocational education dan training, project-based learning

\section{Introduction}

Recently, the gap existing between schools and real life in the community is still open, even getting wider. The consequence of the existing gap in which education is not connected with the real world of work and everyday life contributes to the growing sense of self-worthlessness, alienation, and having no motivation to learn on the part of the students. They see education only as something to be desired, forced, transfered by adults, and not providing them with opportunities to develop skills and a meaningful contribution to others in the community. Therefore, educators, the business community, and the people who are engaged in the development community should realize that schools need to work together in preparing students to become productive citizens. A variety of new learning approaches should be then developed, and these approaches need potentially to connect classroom learning with experiential learning in a broader community. There is such a broad consensus that has increasingly echoed among educators that education needs to change, not just changes in the aspect of what is taught but also in the aspects of how and where learning are performed.
This paper attempts made to set forth several ideas pertaining to the community-based learning programs and their potential to overcome the gaps of what is done in school with what the public demands; strategies of community-based learning program development; projectbased learning as a model of that learning; and a recommendation for carrying out community-based education. To that end, first all, the paper presents concepts of community-based learning, and some of the assumptions underlying its development.

\section{Concepts and Assumptions Community-Based Learning}

Owens and Wang believe that community-based learning as a teaching and learning strategy is significantly wider that allows children and adults to learn what they want to learn from the many segments in society [1]. The meaning of this definition is to provide students of all ages with not only opportunities to decide what they want to learn but also the opportunity to use a variety of sources that exist in the community to support their learning. The term community suggests to us a number of sources in schools, formal and informal institutions that exist around the school, and community resources in the world even the ones that can be obtained via the Internet.

Some assumptions can provide a foundation of paradigm development for community-based learning that has been identified by a team preparing a model of 21st century education [1]. Some of the critical assumptions are as follows.

1) Education should be viewed as a continuum from preschool to adult education.

2) Learning is what we do to ourselves. Therefore, learning requires the involvement of (psychological) individuals who are learning.

3) Future work requires not only a better education, but also the types of different learning which includes critical thinking, teamwork, communication, and abilities to apply knowledge,

4) Adults have a need to be involved in community affairs, and align responsibilities to work, family, and community.

5) The problems faced by young people today are much more extensive and cannot be solved alone by the school. Intricacies of issues around family, employment, business, and other agents in the society who have become part of everyday life of students are an important part that must be faced by the school. 
6) Resistance by some teachers, schools, and communities to change, as reflected by the above assumptions will arise. Therefore, support and empowerment of these groups in order to cultivate the awareness and the need for change is a challenge for leaders in educational institutions. Without this vision, and adequate supports by resources and staff development, the change will not happen.

Departing from these assumptions, a community-based learning paradigm is built on the principle that it is not enough for us only to help students achieve academic skills in school, but we must also strengthen their involvement in productive activities that can deliver them to enter the adult world. For our study, this desire is the ambition, challenge and a real problem simultaneously. Learning challenges like this can be avoided if the stakeholders in the community are involved in the quality assurance of service learning which is best for all students in various types of education. Ambition is only possible through community-based learning.

Because the demands of school-based learning communities are related to institutions and individuals in the community, the instructional actors are necessarily not only teachers, but also partners and mentors from the local community, the workplace, other educational institutions, and organizations around the school. All institutions and individuals can be a potential collaborator for schools in developing life skills of every child, be it in the context of school, home, workplace, or in society.

Vocational education and training is very important for countries with large populations such as Indonesia. An illustration of this can be read in New and Emerging Issues in Vocational Education and Training Research Beyond 2010 [2].

\section{Programs for Community-Based Learning Potentially to Be Developed}

Many programs have been run in schools by applying the essential elements of community-based learning. The body of literature has addressed a number of community-based learning programs known to have a significant contribution to the learning process. These programs include: Servicelearning, Experience-Based Career Education, Cooperative Education, Tech-Prep, and School-to-Work. In Indonesia we know schooling education programs such as career education, practice of field experience, industry practices, job training, expeditions, social work, community service, and others, all learning programs at the school that are carried out outside school. The following section examines the potential programs to be developed into programs of community-based learning in the context of our schooling.

\section{Service-Learning and Social Work}

Service-learning is often viewed as a learning method: 1) in which students learn and develop through active participation in organized activities or useful work to meet the needs of the community and school activities are coordinated with the community; 2) that is integrated into the academic curriculum or provides structured time for students to think, talk of expressions, or write about what they have seen and carried out during the activities in the community; 3 ) that provides students with an opportunity to use academic knowledge and skills in real life situations in their communities; and 4) that extends what is learned in the classroom with learning activities outside the classroom (community) so as to develop social sensitivity towards [3].

Learning methods are characterized by real work experiences by providing this kind of service needs of the community that have been performed by some of our schools in the form of social work or job training. In the 1970s our schools (in Indonesia) made use of Saturday as a Krida's day, a day which is filled with community activities. This activity connects the experience of working in the community with academic learning, personal growth, social sensitivity, and development responsibility as citizens. However, such activities have subsequently disappeared from the school curriculum in line with the increasing load of schools and school orientation on the growth of the value of academic achievement reflected in the NUN score of the National Examination.

Now, learning through real-world experience is a necessity. Programs of service to the school community conducted in collaboration with institutions or individuals in the community, such as hospitals, orphanages, and other social agents, are the meeting point between learning in school and community - the world of work. Real activities such as these contribute to the learning of academic skills and technical skills. Thousands of vocational students of the Information Technology program that have participated intensively to help the transfer of election votes in the recent general election event is an example of service-learning conducted by vocational schools. This is good experiential learning.

\section{A. Cooperative Learning}

Cooperative learning may be a community-based learning program that is most commonly used by schools, particularly vocational schools. Schools or community colleges are in collaboration with the business community in the running of education. The level of coordination between the school staff with the business varies from program to program. In the cooperative education students are usually employed in their jobs that are directly related to the subject at school. In some cases, students receive recognition of their work in addition to guided work that is recognized as part of curricular activities [1].

Cooperative education programs are designed to bridge the gap between the school and the community, which makes the school closer to the real world. Such programs are usually also part of the experience-based career education. In addition to the student's being involved in the real world of work, learning may contain elements of job characteristics, communication and cooperation between individuals' work pathways in the community and the exploration of the real dimensions of the various careers, etc. Dual system of education pioneered in the vocational secondary education in Indonesia is a potential to be developed further into a program of community-based education programs

\section{B. School-to-Work}

The program is popular since the mid-1990s, as a newcomer to the family of community-based learning. The program is developing three main elements: first, it is the program in which school-based learning is associated with 
the development of students' interests, including academic interests, career exploration, and counseling; secondly, it is work-based learning that provides a planned program of job training experience, paid work experience, coaching in the workplace, and general learning competencies, including employability skills, at work or in the various elements of the industry, and finally, activities are related to these two elements through the training of teachers, counselors, and mentors, and schools through collaborative work with business/industry [4].

The idea of an integrated secondary school (Sekolah Menengah Terpadu) -- that integrates academic and vocational learning in the educational programs -- such as those being pioneered by the Education Ministry in the 18 provinces in Indonesia is one form of implementation of School-to-Work that is grafted on high schools [5]. Development of School-to-Work at the middle school level (general and vocational) is potential to address rigid service gaps between the general and vocational education (general high school and vocational school) at the high school level.

\section{Development Strategy for Community-Based Learning Program}

Education and community-based learning require simultaneous actions on many levels - not only in schools, but also at the level of departments and national education offices, partners, and stakeholders in the community. In short, education reform is not only the responsibility of the school. Therefore, the strategy of development of community-based education programs should be mutualistic. A mutual agreement on the responsibility of stakeholders gives a strong sense of purpose and also provides a mechanism for accountability. In a benchmarking strategy, all stakeholders use performance standards to grip and strengthen their contribution to the education reform effort.

There are at least four strategic steps needing to be taken in the development of community-based learning programs.

1) Benchmarking. Performance indicators for each of the responsibilities assumed by each stakeholder group in society should be obvious. These performance indicators are formulated based on the results of selfassessment community (each stakeholder group). For example, a team in the workplace takes part in or conducts student internships, the role of which can be set to be part of the responsibility of the corporate world. Typically, schools are responsible for the administration of intellectual skills and relevant learning experiences, personality formation, expansion of learning opportunities by expanding the classroom to the world of work and society, and to ensure fairness in the delivery of community-based learning experience. Businesses and industries are responsible for workbased learning and related community-based learning in the classroom to develop students' thinking skills, help in the design of integrated and applied curriculum, increase student access to the company and preapprenticeship training, and ensure fairness in the placement of students. The college is responsible for providing access to students' further studies in college and giving credits for the recognition of student competence, providing input into the measurement of performance-based and work-based learning, assisting in the design of the curriculum applied and contextual, and ensuring fairness in the provision of academic support when needed. The local government (Department of Education) is responsible to give supports to community-based learning as a strategy for school change, to collaborate with community leaders to conduct meetings of school-community collaboration, encourage broad-based learning outcomes (academic, persistence, and a high level of performance), high attention to the policy of community-based learning, doing professional development for the implementation of communitybased learning, and ensuring fairness in communitybased learning services for different types of education [6]. Clarity of the benchmark that each stakeholder group has itself would provide a mechanism for accountability.

2) Analysis of action planning. Based on the benchmarks, each stakeholder group conducts action planning. The benchmark is a performance indicator that we want. By looking at existing practices, it can be recognized by the gap between the benchmark to be achieved and existing practices. The next step is an analysis of this gap by identifying opportunities and existing constraints. Based on the analysis of the opportunities and constraints of these, actions will be carried out. The last is setting a way to measure the achievement of benchmarks that have become priorities for action.

3) Development of learning design. The design of community-based learning requires a number of indicators, at least the ones that: (a) comply with the authenticity of the learning using real-world context (for example, problems in the workplace or community) to teach academic and professional discipline; (b) are academically oriented by involving students in the use of inquiry method for the development of higher order thinking skills; (c) are applied to study the involvement of students in learning activities to solve the problem for the expected competencies (e.g. teamwork, problem solving, and communicating); (d) are active exploration activities in the form of an extension of learning beyond the classroom, such as job training, field-based investigations, and explorations of society; (e) involve learning activities that give students opportunities associated with adults by providing a mentor or coaching from the wider society; and (f) involve measurements by involving students in their performance measurement.

4) Planning learning outcomes. Orientation of community-based learning is the development of life skills. Therefore, the desired learning outcomes are not only about what and how much students already know, but also learning outcomes that are pluralistic (multiple outcomes). The hope is that the school will also affect what students can do, or how successfully they apply knowledge; and more than that about what to do next (will do), that is, whether they have a tendency to think of productive habits and their work continues to evolve. Therefore, the focus of the measurement will 
include activities, contents, processes, performance, habits of thought, and behaviors of intelligent students.

These four strategic moves reflect that community-based learning model is complex.

\section{Project-Based Learning as an Example Model}

Project-based learning is a model or an innovative approach to learning, which emphasizes contextual learning through complex activities [7]. The focus is on learning the concepts and the core principles of a discipline of study, involving students in problem solving and investigative tasks, meaningful activities to another, giving students the opportunity to work autonomously to construct their own knowledge, and produce real quality products [8]. In the normative model, Project-Based Learning can be visualized as follows (see Figure 1).

The model usually requires several steps and some duration - not just a series of meetings classes - and collaborative group learning. The project focuses on the development of a product or performance, in which generally students do these activities: organizing learning activities of their group, conducting a study or research, solving problems, and synthesizing information. Projects are often interdisciplinary, for example, a project to design a draft for building structures (construction only), engaging students in investigative activities that influence the environment, making the document development process, and developing a worksheet, which will include the use of concepts and skills drawn from the subjects of mathematics, drafting and/or design, environmental and occupational health, and trade and building materials. According to Alamaki, in addition that, projects need to be undertaken collaboratively; projects must also be innovative, unique, and focused on solving problems related to student life or the needs of the local community or industry [9].

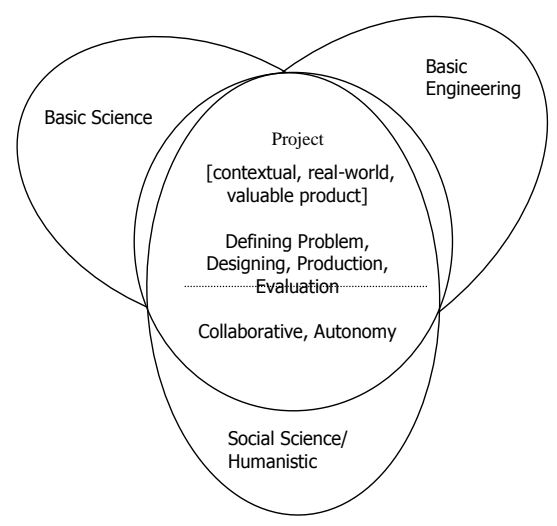

Figure 1. Project-Based Learning [10]

Project Based Learning has a huge potential to make the learning experience more interesting and meaningful for students aged adults, be they studying in college or transitional training in its School-to-Work to enter the workforce [11]. In Project Based Learning, students become more actively encouraged in their learning, the instructor and the student play behind the initiative; instructors provide a conducive atmosphere of learning comfort and evaluate the project both its significance and its application to their daily lives. Products made of students during the project provide results that are authentic that can be measured by a teacher or an instructor and the students themselves. Therefore, in the Project-Based Learning, the teachers or instructors should be not only more active and direct the students' activities, but they play a role as a partner, or a facilitator, and more importantly they understand the students.

Student projects can be prepared in collaboration with the instructor, while students learn in collaborative groups of 4-5 people. When students work in teams, they find the skills to plan, organize, negotiate, and build consensus on issues of task to be completed: who is responsible for each task, and how the information will be collected and presented. Skills that have been identified by these students are very important skills for success in life, and labor is a very important skill in the workplace. Due to the fact that the nature of work is a collaborative project, the ongoing development of these skills among students needs to be accurately monitored. In a project group work, individual strengths and learning styles are considered substantially to strengthen the work of the team as a whole.

Projects in Project-Based Learning are the center or core curriculum, not complementing to the curriculum. In the Project-Based Learning, the project is a learning strategy; students experience and learn the core concepts of a discipline through the project. There is a project work that follows the traditional learning with the project illustrating how, for example, additional practice, or application practice is previously taught with other purposes. However, according to the criteria presented previously, this project application may not be categorized as a Project Based Learning. Project activities are intended for enrichment outside the curriculum which does not include Project-Based Learning.

Projects in Project-Based Learning are focused on questions or problems, which encourages students to live with (hard work) concepts and core principles of the discipline or subject. This criterion is very smooth and rather difficult to be touched. Definition of the project (for students) must be made in order to create a relationship between activity and conceptual knowledge that is expected to develop to be wider and deeper [12]. Projects in ProjectBased Learning might be built around thematic units, or a combination (intersection) of topics from two or more disciplines. However, this is not yet fully considered to be a project if the questions are rushing students, commensurate with the activities, products, and performance that fill their time, not composed in tasks that aim at intellectual elaboration [13].

Projects involve students in a constructive investigation. Investigations may include the design process, decisionmaking, problem-finding, problem solving, discovery, or the model development process. However, in order to meet the criteria of a project called Project-Based Learning, the core activity of the project should include the transformation and construction of knowledge (in the sense of new insights, or new skills) on the part of students [14]. If the center or core of the project activity does not present a "degree of difficulty" for the child, or can be completed with the application of information or skills which are ready to be learnt, the project in question is nothing more than an exercise, and not the project as Project Based Learning. 
Cleaning of laboratory equipment may be a project, but may not project in the Project-Based Learning.

The project encourages students to reach significant levels. Projects in Project-Based Learning are not a teacher creation. It is said in the script. Laboratory exercises are not an example of Project-Based Learning unless it focuses on the problems and the core curriculum. Projects in ProjectBased Learning do not end at a pre-determined result or take the path (procedures) that have been previously defined. Project Based Learning prioritizes autonomy, choice, labor time that is not rigid, and the responsibility of the student rather than the traditional project of learning.

The project is realistic. Characteristics of the project provide students with an authenticity of experiences. These characteristics may include topics, tasks, roles played by students, the context in which the project work is accomplished, collaborators who work with students on projects, products produced, the audience for the products of the project, or the criteria on which the products or performance is assessed. Project Based Learning involves the challenges of real life, focusing on the question or issue authentic (not simulative), and the solution has the potential to be applied in the real field.

Project-based learning can be revolutionary in the issue of learning. Projects can change the nature of the relationship between a teacher and students. Projects are to reduce competition in the classroom, and engage students to have more collaborative activities than work individually. Projects can also shift the focus of learning from the facts given to the exploration of ideas.

\section{Sample Implementation Project-Based Learning}

In the design of the Project Based Learning, it is developed based on at least three main pillars, namely: 1) contextual, 2) collaborative, and 3) autonomous. With these three main pillars, the Project Based Learning procedure is designed in six stages as follows [15].

1) Students are faced with real problems in the community, and are encouraged to identify the real problem (by searching it). In this example, students are encouraged to study the environment of small and medium industries that employ advanced machinery and experienced production problems. In a collaborative work group, students identify production problems and define the problem to be solved through project work.

2) Students are asked to find an alternative and formulate problem solving strategies (problem solving). At this stage, the working group is guided to collect information, multidisciplinary literature review, and formulate the problem solving strategies using concepts or principles of machining technology.

3) Students are guided in planning (designing). At this stage, a working group is led to build "artifacts" (product model technology to be realized). Perhaps students do the analysis/construction calculations, calculation of materials, production procedures and formulated using data processing equipment and design (AutoCAD or Mechanical Desktop, for example).

4) Students are guided to produce a tool or machine that has been designed in the previous stage (producing/creating). At this stage, the working group is guided to make products, as has been designed in the previous stage. The activities at this stage of the project work involve various types of machining jobs, which may be performed in parallel groups. Group members may perform engine work, while others may perform welding work, or perhaps sheet-metal work.

5) Students are guided to conduct product testing (evaluating). Students perform a self-test to determine the performance of the products produced by the tools, and to know the advantages and disadvantages. The process of this trial is a form of self-evaluation which is feedback to the performance of their projects.

6) Students are required to have presentations between groups (sharing). This presentation is intended to communicate the actual creation or discovery of new technologies that can address specific production problems. This stage will stimulate the emergence of questions / new experiences that will trigger new ideas of the next technology.

\section{Notes and Recommendations}

This paper has discussed the potentials and advantages of community-based learning as a strategy for educational reform. However, the experience has shown that a number of educational reforms in Indonesia are not run as smoothly as those expressed on papers. These paper works indicate that there are a lot of educators who are essentially spirited reformers.

From an ideological perspective, many educators are still loyal to the old educational paradigm, where the purpose of education is to transfer knowledge to the contents of the child's head. In the old paradigm, there is no need as input from students about what will be learned, when, where, or how. Under the new paradigm of community-based education, more teachers serve as a mentor who guides student learning. That is, in the application of the new paradigm of community-based learning, in addition to the system, the learning organization is prepared, and a mechanism for the development of educational personnel, especially teachers needs to be systematically developed

From a practical perspective, community-based learning requires a strong commitment from the top leadership to the dedicated teachers. Community-based learning requires time, effort, and cost. Teachers need to work individually with students in the identification and planning purposes, the involvement of the community, and to help students learn from their experience. Another practical consideration that needs taking into account is the time when students are doing activities outside of school. There are barriers to transformation and the need for a block schedule so it needs time for students to meet. Orientation training for prospective teachers, and mentors from the community are also very important to be considered.

\section{References}

[1] T.R. Owens, \& C. Wang, "Community-based learning: A foundation for meaningful educational reform". School Improvement Research Series (SIERS), 1996, Topical Synthesis \# 8. 
[2] C. Beduwe, J.F. Germe,T. Leney, J. Planas, M. Poumay, \& R. Armstrong, "New and emerging issues in vocational education and training research beyond 2010", in Modernising Vocational education and Training: Fourth report on vocational training research in Europe, Background report, Vol. 2, Luxembrug: European Centre for the Development of Vocational Training, 2009, p. 17-72.

[3] Alliance for Service-learning in Education Reform, "Standards for quality for school-based servicelearning", Equity and Excellencen Education, 26(2), 1993, p. 71-73.

[4] C. Zirkle, C. "Perceptions of vocational educators and human resource/training and development professionals regarding skill dimensions of school-to-work transition programs. Journal of Vocational and Technical Education, 1997, 15(1). http://scholar.lib.vt.edu/ejournals/JVTE/v15n1/JVTE7.html

[5] Waras Kamdi, "Integrating academic and vocational education in Indonesia". Prosiding Seminar Internasional Reorientasi Paradigma Baru Pendidikan Kejuruan yang diselenggarakan oleh Aptekindo, Makassar, Indonesia, 3-5 Mei 2012.

[6] C. Almeida, \& A. Steinberg, "Connected learning communities: A toolkit for reinventing high school". JFF, National Faculty and the US Department of Education, 2001.

[7] J.W. Thomas, J.R. Mergendoller, \& A. Michaelson, "Project-Based Learning: A Handbook for Middle and High School Teachers". Buck Institute for Education, 1999. http://www.bie.org.

[8] J.W. Thomas, "A Review of research on project-based learning". http://www.autodesk.com/foundation.

[9] A. Alamaki, "Current Trends in Technology Education in Finland". The Journal of Technology Studies. 1999, Available on: Digital Libraries and Archives.

[10] Waras Kamdi. "Pembelajaran berbasis proyek: Pendekatan inovatif pembelajaran kejuruan”. Jurnal Teknologi Pembelajaran: Teori dan Penelitian, 2003, 11 (1), 3-16.

[11] S. Gaer, "What is Project-Based Learning?", 1998, http://members.aol.com/CulebraMom/pblprt.html.

[12] B.J. Barron, D.L. Schwartz, N.J. Vey, A. Moore, A. Petrosino, L. Zech, J.D. Bransford, \& The Cognition and Technology Group at Vanderbilt. "Doing with understanding: Lessons from research on problem- and project-based learning. The Journal of the Learning Sciences, 1998, 7, 271-311.

[13] P.C. Blumenfeld, E. Soloway, R.W. Marx, J.S. Krajcik, M. Guzdial, and A. Palincsar. "Motivating project-based learning: Sustaining the doing, supporting the learning". Educational Psychologist, 26 (3 \& 4), 369-398.

[14] C. Bereiter, \& M. Scardamalia, M., Process and Products in PBL Research. Toronto: University of Toronto, 1999.

[15] Waras Kamdi, The effects of instructional model and learning style toward academic, technical, and problem solving skills in the mechanical field, Monograph, Malang: Cakrawala-Indonesia, 2010. 